Jurnal e-Clinic (eCl), Volume 3, Nomor 1, Januari-April 2015

\title{
GAMBARAN PENGETAHUAN SISWI SMP TENTANG KEHAMILAN REMAJA
}

\author{
${ }^{1}$ Billy Narasiang \\ ${ }^{2}$ John Wantania \\ ${ }^{2}$ Maya Mewengkang
}

\author{
${ }^{1}$ Kandidat Skripsi Fakultas Kedokteran Universitas Sam Rtulangi Manado \\ ${ }^{2}$ Bagian/SMF Obstetri Ginekologi Fakultas Kedokteran Universitas Sam Ratulangi Manado
}

\begin{abstract}
Teenage pregnancy associated with negative consequences for parents, their children, and society. Lack of knowledge of sex and domestic life becomes a major factor of teenage pregnancy and significantly associated with medical and psychosocial risks.To determine the junior high school student knowledge about teenage pregnancy.This research was conducted in a descriptive way through survey method by distributing questionnaires in three junior high schools in the city of Manado, namely, SMP 7 Manado, Eben SMP and SMP Haezar 1 Manado Manado Eben Haezar 2.Of the 183 respondents, the highest obtained at the age of 14 years (55.7\%). Most respondents (73.8\%) had a good knowledge level. Sources of information about teen pregnancy is the most established through the mass media. The influence of the mass media in conveying information about sexual and reproductive health provides good information.Most respondents have a good knowledge about teenage pregnancy and through mass media many teenagers get resources on teen pregnancy.
\end{abstract}

Keywords: knowledge, student, junior high school, teenage pregnancy

\begin{abstract}
Abstrak: Kehamilan remaja berhubungan dengan akibat negatif bagi orang tua, anak mereka, dan masyarakat. Kurangnya pengetahuan seks dan kehidupan rumah tangga menjadi faktor utama kehamilan remaja dan berhubungan secara bermakna dengan resiko medis dan psikososial. Untuk mengetahui pengetahuan siswi SMP tentang kehamilan remaja. Penelitian ini dilaksanakan dengan cara deskriptif melaui metode survei dengan cara membagikan kuesioner di tiga SMP di Kota Manado yaitu, SMP Negeri 7 Manado, SMP Eben Haezar 1 Manado dan SMP Eben Haezar 2 Manado. Dari 183 responden, didapatkan terbanyak pada usia 14 tahun (55,7 \%) . Sebagian besar responden (73,8 \%) memiliki tingkat pengetahuan baik. Sumber informasi mengenai kehamilan remaja yang terbanyak didapatkan melalui jalur media massa. Pengaruh media massa dalam menyampaikan informasi mengenai seks dan kesehatan reproduksi memberikan informasi yang baik. Sebagian besar responden memiliki pengetahuan yang baik tentang kehamilan remaja dan melalui media massa remaja banyak mendapatkan sumber informasi tentang kehamilan remaja.
\end{abstract}

Kata kunci: pengetahuan, siswi, smp, kehamilan remaja

Menurut WHO (World Health Organization) remaja merupakan anak yang telah mencapai usia 10-18 tahun untuk anak perempuan dan 12 sampai 20 tahun untuk anak laki-laki. Menurut The Health Resources and Services Administrations Guidelines Amerika Serikat, rentang usia remaja adalah 11-21 tahun. $^{1,2}$ Kehamilan Remaja adalah kehamilan yang terjadi pada wanita berusia di bawah 20 tahun. Kehamilan di bawah usia 20 tahun dapat menyebabkan kematian pada ibu akibat anatomi organ yang belum sempurna sehingga bisa menyebabkan anemia, preeklampsia, eklampsia, abortus, partus prematurus. ${ }^{3}$ Hamil di usia remaja 
juga berpeluang besar dilakukan persalinan secara caecar karena persalinannya lama dan sulit. Selain itu remaja yang hamil juga secara mental belum siap dengan kehamilannya sehingga dapat meyebabkan asupan gizi yang dikonsumsi tidak cukup atau kurang seimbang. ${ }^{4}$

Di Indonesia,Badan Kependudukan dan Keluarga Berencana (BKKBN), mengeluhkan tingginya usia kehamilan pada remaja Indonesia saat ini, bahkan menurut survei terakhir dari Badan Pusat Statistik (BPS) melalui Survei Demografi dan Kesehatan Indonesia (SDKI), tahun 2012 angka kehamilan remaja pada kelompok usia 15 -19 tahun mencapai 48 dari 1.000 kehamilan, lebih tinggi dibandingkan tahun 2010 sebesar 30 dari 1.000 kehamilan. $^{5}$ Berdasarkan fakta tingginya angka kehamilan pada remaja dan konsekuensi yang ditimbulkan karena kehamilan remaja, maka penulis tertarik untuk meneliti bagaimana pengetahuan siswi SMP tentang kehamilan remaja.

\section{METODE PENELITIAN}

Penelitian ini bersifat deskriptif melalui metode survei dengan cara membagikan kuesioner kepada siswi SMP kelas IX. Penelitian dilakukan di SMP Negeri 7 Manado, SMP Eben Haezar 1 Manado, dan SMP Eben Haezar 2 Manado selama bulan November 2014. Variabel penelitian adalah gambaran pengetahuan siswi SMP tentang kehamilan remaja.

\section{HASIL PENELITIAN}

Dari seluruh siswi yang dilakukan penelitian pada bulan November 2014 besar sampel dalam penelitian ini adalah 183 siswi yang terdiri dari 90 siwi SMP Negeri 7 Manado (A) , 46 siswi Eben Haezar Manado (B) , dan 47 siswi SMP Eben Haezar 2 Manado (C) .

Pada variabel usia sesuai tabel 1 didapatkan bahwa responden terbanyak pada ketiga sekolah yang diteliti adalah remaja berumur 14 tahun $(55,4 \%)$.

Pada penelitian ini dilihat juga tingkat pengetahuan siswi tentang kehamilan remaja di ketiga sekolah tersebut secara rata-rata siswi dari ketiga sekolah tersebut memiliki tingkat pengetahuan yang baik tentang kehamilan remaja.

Tabel 1. Karakteristik responden berdasarkan umur

\begin{tabular}{|c|c|c|c|c|c|c|c|c|}
\hline \multirow[t]{2}{*}{ Umur } & \multicolumn{2}{|l|}{ A } & \multicolumn{2}{|l|}{ B } & \multicolumn{2}{|l|}{ C } & \multicolumn{2}{|l|}{$\begin{array}{c}\text { Tota } \\
\text { l }\end{array}$} \\
\hline & $\begin{array}{l}\mathrm{n} \\
(90 \\
) \\
\end{array}$ & $\%$ & $\begin{array}{l}\mathrm{n} \\
(46)\end{array}$ & $\%$ & $\begin{array}{l}\mathrm{n} \\
(47)\end{array}$ & $\%$ & $\begin{array}{c}\mathrm{n} \\
(183 \\
()^{2} \\
\end{array}$ & $\%$ \\
\hline 12 & 1 & 1,2 & 1 & 2,2 & - & - & 2 & 1,1 \\
\hline 13 & 40 & 44,4 & 26 & 56,5 & 13 & 27,7 & 79 & 43,2 \\
\hline 14 & 49 & 54,4 & 19 & 41,3 & 34 & 72,3 & 102 & 55,7 \\
\hline Total & 90 & 100 & 46 & 100 & 47 & 100 & 183 & 100 \\
\hline
\end{tabular}

Tabel 2. Distribusi Frekuensi Responden berdasarkan tingkat pengetahuan siswi tentang kehamilan remaja di sekolah A,B, dan $\mathrm{C}$

\begin{tabular}{lcccccccc}
\hline $\begin{array}{l}\text { Pengetah } \\
\text { uan }\end{array}$ & A & \multicolumn{1}{c}{ B } & & C & & & \\
& & & & & & & Total & \\
\cline { 2 - 8 } & $\mathrm{n}$ & $\%$ & $\mathrm{n}$ & $\%$ & $\mathrm{n}$ & $\%$ & $\mathrm{n}$ & $\%$ \\
& & & & & & & & \\
\hline Baik & 60 & 66 & 40 & 87 & 35 & 74 & 135 & 73, \\
& &, 7 & &, 0 & &, 5 & & 8 \\
Kurang & 30 & 33 & 6 & 13 & 12 & 25 & 48 & 26, \\
& &, 3 & &, 0 & &, 5 & & 2 \\
Total & 90 & 10 & 46 & 10 & 47 & 10 & 183 & 10 \\
& & 0 & & 0 & & 0 & & 0
\end{tabular}

Responden memperoleh informasi tentang kehamilan remaja paling dominan dari media massa (Tabel 3).

Tabel 3. Distribusi Responden Berdasarkan Sumber Informasi tentang kehamilan remaja

\begin{tabular}{lcccccc}
\hline $\begin{array}{l}\text { Sumber } \\
\text { Informasi }\end{array}$ & $\mathrm{A}$ & $\%$ & $\mathrm{~B}$ & $\%$ & $\mathrm{C}$ & $\%$ \\
\cline { 2 - 7 } & $\mathrm{n}$ & & $\mathrm{n}$ & & $\mathrm{n}$ & \\
\hline OrangTua & 68 & 22,2 & 40 & 20 & 39 & 21,5 \\
Guru & 62 & 20,3 & 41 & 20,4 & 42 & 23,2 \\
Sosial & 31 & 10,2 & 35 & 17,4 & 27 & 14,9 \\
Media & $\mathbf{7 6}$ & $\mathbf{2 4 , 8}$ & $\mathbf{4 6}$ & $\mathbf{2 2 , 8}$ & $\mathbf{4 3}$ & $\mathbf{2 3 , 8}$ \\
Internet & 69 & 22,5 & 39 & 19,4 & 30 & 16,6 \\
\hline
\end{tabular}


Didapatkan bahwa sumber informasi pengetahuan siswi tentang kehamilan remaja sebagian besar diperoleh dari media massa yangg mendapat pengetahuan baik yaitu 116 siswi (Tabel 4).

Tabel 4. Distribusi sumber informasi responden dengan pengetahuan tentang kehamilan remaja

\begin{tabular}{lcc}
\hline \multicolumn{1}{c}{$\begin{array}{c}\text { Sumber } \\
\text { Informasi }\end{array}$} & Pengetahuan & Siswi \\
\cline { 2 - 3 } & Baik & Kurang \\
\hline Orang Tua & 101 & 34 \\
Guru & 100 & 35 \\
Sosial & 65 & 25 \\
Media & 116 & 41 \\
Internet & 103 & 33 \\
\hline
\end{tabular}

\section{BAHASAN}

Responden pada penelitian merupakan siswi SMP kelas IX yang usia paling banyak berumur 14 tahun dan diketahui responden terdistribusi umur 12-14 tahun (Tabel 1). Dengan data ini juga dapat terlihat kesesuain tentang distribusi umur dengan batasan remaja menurut WHO,yaitu remaja awal 10-14 tahun. Awal masa remaja ini disebut dengan masa pubertas atau masa akil baligh. ${ }^{6}$

Pengetahuan siswi tentang kehamilan remaja yang baik (Tabel 2) dapat menjadi faktor positif untuk menghindarkan remaja dari pergaulan bebas yang bisa memicu terjadinya kehamilan dini. Pengetahuan yang baik dapat memberikan remaja menghindari kehamilan remaja. Informasi yang tersedia baik melalui media massa,internet dan sumber lain dapat menjadi referensi yang baik bagi remaja untuk mengetahui segala sesuatu tentang kehamilan remaja, namun di sisi lain informasi yang kurang jelas dan minim, dapat meningkatkan rasa keingintahuan remaja. Rasa keingintahuan yang besar dapat menjadi stimulus remaja untuk melakukan hubungan seksual diluar nikah sehingga dari tahun ke tahun kehamilan remaja meningkat. Dalam kenyataannya walaupun pengetahuan remaja tentang kehamilan remaja itu baik, namun kurang mempengaruhi tingginya angka kehamilan remaja. Dapat disimpulkan bahwa selain pengetahuan tentang kehamilan remaja, ada faktor-faktor lain yang mempengaruhi peningkatan kehamilan remaja dari tahun ketahun. Perlu penelitian lebih lanjut tentang faktor-faktor yang berperan dalam meningkatnya kehamilan remaja.,

Responden memperoleh informasi tentang kehamilan remaja paling dominan dari media massa (Tabel 3). Artinya media massa mempunyai pengaruh yang besar dalam hal responden memperoleh informasi tentang kehamilan remaja. Dapat disimpulkan bahwa peranan orang tua dan guru sebagai lini pertama pendidikan seks pada remaja, ternyata telah digantikan oleh media massa dan internet. Dengan adanya kemajuan dibidang IPTEK, memudahkan remaja untuk mengakses informasi dari media atau internet. Komunikasi yang lebih terbuka antara anak dan orang tua, dapat berperan penting dalam pemantauan perilaku anak di masyarakat. Pergaulan yang salah dan penyalahgunaan media dapat menyebabkan perubahan pola pikir pada remaja tentang kehamilan remaja, sehingga mereka menganggap bahwa seks pranikah hingga menyebabkan kehamilan merupakan suatu hal yang lazim. Informasi yang cukup tentang seksualitas yang anak dapatkan dari orang tua, dapat meminimalisasi keingintahuan anak untuk mengakses informasi di luar rumah (Internet, media cetak, teman sebaya, maupun pacar). ${ }^{9}$

Distribusi sumber informasi responden dengan pengetahuan tentang kehamilan remaja didapatkan bahwa mayoritas responden dengan kategori tingkat pengetahuan baik diperoleh dari media massa sebanyak 116 responden dan minoritas responden untuk sumber informasi pengetahuan kurang ada pada sosial sebanyak 25 responden (Tabel 4). Teori Piaget menyebutkan bahwa remaja cenderung untuk membangun pengetahuannya dari informasi yang mereka dapat yaitu dari media massa, teman, maupun orangtua. Remaja 
menggabungkan pengalaman dan pengamatan mereka untuk membentuk pengetahuan mereka dan menyertakan pemikiran-pemikiran baru yang mereka dapatkan dari sumber informasi karena tambahan informasi akan mengembangkan pemahaman mereka tentang suatu pengetahuan. Pengaruh media massa dalam menyampaikan informasi mengenai seks dan kesehatan reproduksi mempunyai pengaruh yang paling besar, informasi tentang seks yang diterima oleh remaja melalui media massa tidak selalu memberikan efek negatif. ${ }^{10,11}$

\section{SIMPULAN}

Dari hasil penelitian pengetahuan siswi SMP tentang kehamilan remaja yang dilakukan di tiga SMP di Kota Manado dengan kesimpulan sebagai berikut.

1. Sebagian besar responden telah memiliki pengetahuan yang baik tentang kehamilan remaja.

2. Responden mendapat informasi tentang kehamilan remaja paling banyak melalui media massa.

\section{SARAN}

1. Peran serta orang tua dalam mendidik anak remaja merupakan hal yang paling penting untuk menghindarkan anak dari kemungkinan kehamilan usia remaja.

2. Meningkatkan ketahanan keluarga dengan menciptakan keluarga yang harmonis, sehat, dan religius.

3. Meningkatkan tugas guru selain sebagai pengajar akademis, juga sebagai tempat bimbingan dan konsultasi bagi pelajar khususnya mengenai masalah kehamilan remaja.

4. Pendidikan seks dan kesehatan reproduksi sejak dini perlu diberikan kepada remaja baik itu melalui orang tua maupun guru di sekolah melalui pelajaran biologi.
5. Untuk para pelajar agar lebih membekali diri dengan pengetahuan tentang kehamilan, mengisi waktu dengan halhal yang lebih bermanfaat.

\section{DAFTAR PUSTAKA}

1. Carolli G, Ferguson J, Whyte $\mathbf{P}$. Preventing Early Pregnancy and Poor Reproductive Outcomes among adolescents in developing countries. WHO guideline. World Health Organization. 2011.

2. Merenstein, et al. Buku Pegangan pediatri. Jakarta : widya medika Nazir; 2002.

3. Vorvick Linda, MD. Teen pregnancy. University of Maryland. 2009. Available at http://www.medicalcentre.com

4. UNICEF. Adolescent an age of opportunity. The state of the world's children 2011. 2011.p 8-57.

5. Rahmadan H. Meningkatnya usia kehamilan remaja. Available at : Jurnal perempuan. Untuk pencerahan dan kesetaraan. Media Indonesia. 28 Mei 2013.

6. Prawirohardjo, Sarwono. Pelayanan Kesehatan Maternal dan Neonatal. Jakarta: YBP- SP, 2006.p 58.

7. Wagner B. Teen pregnancy prevention program: Teens' Attitudes towar sexuality. A research paper. Ball State University. Indiana. 2009.

8. McKay A. Trends in Canadian National and Provincial/Territorial Teen Pregnancy Rates: 2001-2010. The Canadian Journal of Human Sexuality, 2012. p 161-73

9. Dickins TE, Johns SE, Chipman A. Teenage pregnancy in the United Kingdom: the behavioral ecological perspective. Theoretical contribution. Journal of Social, Evolutionary, and Cultural Psychology. 2012;6:344-59.

10.Dianawaty, Anjen. Pendidikan dan Seks untuk Remaja. Jakarta; 2003. p 8-9.

11.Santrock, John W. Adolescence Perkembangan Remaja. Jakarta: Erlangga; 2003.p 439. 